\title{
Pd-Catalyzed Asymmetric Ring Opening of Azabenzonorbornadienes
}

\section{Gategory}

Metal-Catalyzed

Asymmetric

Synthesis and

Stereoselective

Reactions

\section{Key words}

asymmetric ring opening

azabenzonorbornadienes

chiral spiro ligands

palladium<smiles>CC(C)(C)OC(=O)C1C=Cc2ccccc2C1NC(=O)c1cccc(F)c1</smiles>

$80 \%$ yield, $85 \%$ ee<smiles>O=C1NC2c3ccccc3C=CC2c2cc(Cl)ccc21</smiles>

$67 \%$ yield, $76 \%$ ee
(MeCN)

$\mathrm{Zn}$ (10 equiv), $\mathrm{I}_{2}\left(1\right.$ equiv), Et ${ }_{3} \mathrm{~N}$ (0.5 equiv)

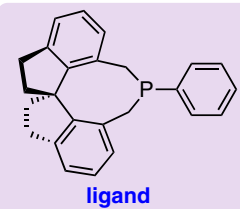<smiles>COc1ccc2c(c1)C(=O)NC1c3ccccc3C=CC21</smiles>

$82 \%$ yield, $81 \%$ ee<smiles>O=C1NC2c3ccccc3C=CC2C2=CC[Te]CC=C12</smiles><smiles>O=C1NC2c3ccccc3C=CC2c2ccc(OC(F)(F)F)cc21</smiles>

$78 \%$ yield, $80 \%$ ee

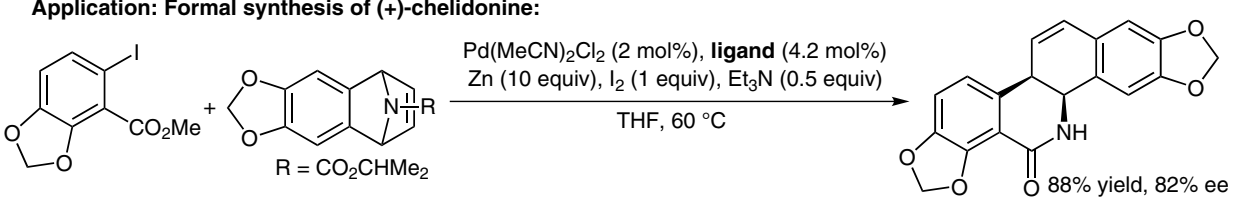

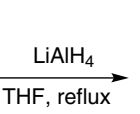<smiles>C1=CC2c3ccc4c(c3CNC2c2cc3c(cc21)OCO3)OCO4</smiles>

$\underset{\mathrm{CH}_{2} \mathrm{Cl}_{2}, \text { r.t. }}{\mathrm{CbzCl}, \mathrm{Et}_{3} \mathrm{~N}}$<smiles>O=[N+]([O-])N1Cc2c(ccc3c2OCO3)C2C=Cc3cc4c(cc3C21)OCO4</smiles><smiles>C#CC=C</smiles><smiles>O=[N+]([O-])N1Cc2c(ccc3c2OCO3)C2C1c1cc3c(cc1C[C@@H]2O)OCO3</smiles>

Significance: In the presence of electron-rich chiral spirophosphine ligands, $\mathrm{I}_{2}$ as key additive, and zinc powder as reducing agent, $\mathrm{Pd}(\mathrm{MeCN})_{2} \mathrm{Cl}_{2}$ efficiently catalyzes the ring opening of azabenzonorbornadiene with various 2-iodobenzoates. The resulting enantioenriched cis-dihydrobenzo[c]phenanthridinones serve as core structure of numerous optically active natural products.
Comment: The use of easily available organic halides instead of organometallic reagents and the construction of fused ring systems with multiple stereocenters via the tandem asymmetric ringopening-cyclization process make the strategy remarkably efficient. A direct application of the present methodology was demonstrated via the concise total synthesis of $(+)$-chelidonine.

SYNFACTS Contributors: Hisashi Yamamoto, Sukalyan Bhadra 